\title{
AdvocaCy in The NeW MiLlenNiUM ${ }^{1}$
}

\author{
FRED FERGUSON, Q.C.*
}

Practicing good advocacy in the new millennium may not be that different than it was in the century just past. What is different are some of the new challenges to be faced in becoming and remaining an effective and successful advocate. The foundations of skillful advocacy are best set down at the outset of one's legal career, and the development of the art must at all times be considered from its human, legal, and ethical sides. While the evolution of the practice of law is built upon the careful and steady historical ascendancy of precedent, there are practices and rules in our age that need to be critically examined. In this lecture, delivered before an audience comprised mainly of people newly entering the legal profession, the author shares his thoughts on the contemporary practice and ethical strictures of good advocacy. He draws on a wide body of knowledge, personal experience, and established practices in the legal profession, and imparts lessons on a thorough range of advocacy topics, including the importance of preparation and presentation, the art of examination and cross examination of witnesses, and tactics for addressing juries.
La pratique de bons services d'assistance judiciaires au nouveau millénaire n'est peut-être pas aussi différente qu'au siècle dernier. Toutefois certaines des difficultés auxquelles il faut faire face pour devenir et demeurer un avocat efficace et à succès sont différentes. Il est bon d'établir les assises d'une plaidoirie habile au début de sa carrière, et le perfectionnement de cet art doit à tout moment être considéré des points de vue humain, juridique et éthique. Alors que l'évolution de la pratique du droit repose sur l'ascendance soignée et historiquement soutenue de précédents, il existe de nos jours des pratiques et des règles qu'il faut examiner d'un xil critique.

Dans cette conférence donnée devant un auditoire composé de personnes qui viennent d'entrer dans la profession juridique, l'auteur nous dit ce qu'il pense de la pratique contemporaine et des constrictions éthiques dans l'art d'être un bon avocat. Il s'inspire d'un vaste bloc de connaissances, d'expériences personnelles et de pratiques établies dans le domaine juridique et tire des leçons pertinentes à une vaste gamme de sujets, y compris l'importance de la préparation et de la présentation, l'art de l'interrogatoire et du contre-interrogatoire des témoins et les tactiques à utiliser avec les membres du jury.

\section{TABLE OF CONTENTS}

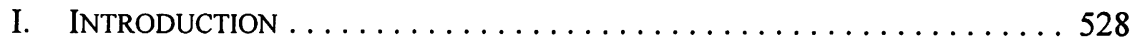

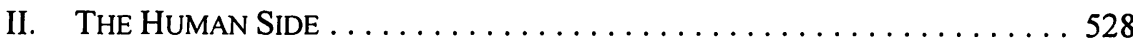

III. THE LEGAL SIDE . . . . . . . . . . . . . . . . . . . . . . . . . . . . . . 529

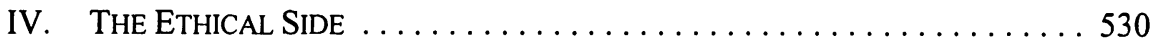

V. PREPARATION .......................... 531

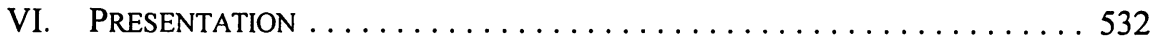

VII. EXAMINATION OF WITNESSES $\ldots \ldots \ldots \ldots \ldots \ldots \ldots \ldots \ldots \ldots \ldots$

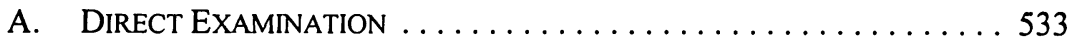

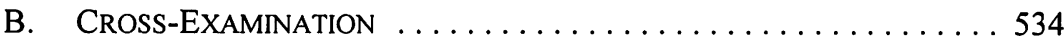

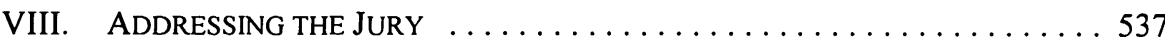

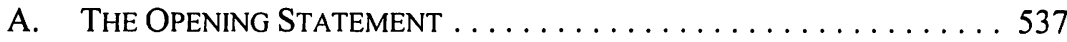

Regional Crown Prosecutor, Miramichi, N.B. Department of the Attorney-General, Province of New Brunswick. The views expressed in this lecture are those of the author and not of the Office of the Attorney-General of New Brunswick.

1 The Milvain Lecture, 2002, The School of Law, University of Calgary. The Milvain Chair of Advocacy was instituted at The School of Law at the University of Calgary in 1978 in honour of M.V.A. Milvain, Chief Justice of the Court of Queen's Bench of Alberta. The first holder of the Chair was John J. Robinette, considered by many to be perhaps Canada's greatest advocate. Since that time, esteemed advocates from across the country have occupied the position. 
B. THE Closing Address $\ldots \ldots \ldots \ldots \ldots \ldots \ldots \ldots \ldots \ldots \ldots \ldots$

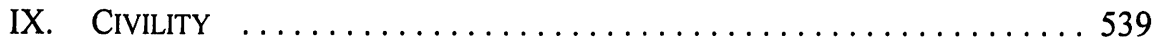

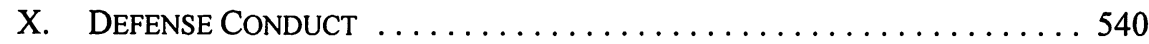

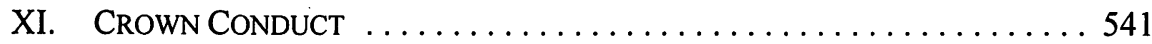

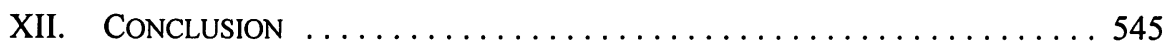

\section{INTRODUCTION}

There have been countless volumes written over the centuries by legal scholars, practitioners, and judges on the subject of advocacy in an attempt to capture the essence of this art. What a prosecutor who has spent his entire career plying his trade in rural New Brunswick might have to add to this ageless pursuit is a matter of some curiosity, I am sure. Nonetheless, lawyering has certain common and timeless features no matter the place, age, or speed of change in the world.

Much of what I will say here is part of an age-old template honed over the years through carefully thought-out practices resulting from incremental change brought about by some of the greatest advocates our history has known.

Advocacy has been described by many of our predecessors. It has been the subject of careful analysis over the millennia by the masters of this profession. Hopefully, some of what I say, if not innovative, will provoke your thoughts and be of assistance to you as you embark on your career as an advocate.

\section{The Human Side}

At the outset it should be observed that there is no one human trait or series of traits that will make one more likely to become an effective and successful advocate. Raw intelligence and some oratorical skills, though essential ingredients in the recipe for producing a competent advocate, are by no means guarantees of success. Rather, as with most people who have found success in their chosen field, the critical common traits of successful advocates include a healthy passion for the work they do and a commitment to excellence through hard work.

Many of you have already been exposed at one level or another to good advocacy. You have seen lawyers of all physical shapes and sizes who have cobbled together effective styles with a myriad of skills of varying quantities that add up to a winning combination. My own view is that an effective style is very much a product, first of all, of being yourself and, secondly, of being an introspective human being. That means understanding who it is you are as a person, in an objective sense, with all of your strengths and weaknesses. This will necessarily involve an ongoing process of self-assessment and reassessment as you grow in life and your professional experiences throughout your career. It has been said that to be happy in life, one must continue to grow as a human being throughout life. The same is surely true of great advocates. They are never content to rest on their laurels, but continue to challenge new frontiers of learning, committing themselves to improving and refining their skills throughout their careers. 
The exhilaration of participating in the adversarial process is something that may evoke enough passion in the young advocate to enable her or him to commit to the work that must be done to ensure, as much as is possible, a successful outcome. Truly great advocates, however, are those individuals who bring out the best in themselves over a long career, time and time again. That kind of longevity and quality performance involves a commitment to excellence rooted not so much in passion, but in the core values of hard work, a commitment to serve others, and a steadfast refusal to accept less than the best from oneself.

Hockey is our national sport. It has been said that the great players of our time, such as Wayne Gretsky and Mario Lemieux, transcended the game and played it on a level beyond that of other players. As such, those players are involved in more than a game of hockey each time they step on the ice. The same can be said of great advocates. While concentrating primarily on the task at hand, they are focused on a great many other things: that may include building and maintaining their reputation for future challenges while looking at both the macro and the micro picture presented by any particular proceeding - including the professional commitment they have made to assist the court in finding truth.

\section{The Legal Side}

It is important to remind ourselves that we are involved in a profession that has a long and distinguished history. What we do and the rules we live by as advocates have been built incrementally over the centuries through tried and tested methods. Thus, books and articles on advocacy can help to educate us in the tried and tested methods of others that have been found to produce success in this profession. I commend these to you.

My own observations over the last quarter century of practice also seem to confirm that, like ducklings imprinting with their mother, we assume many of the traits of those advocates with whom we are first associated in the practice of law. If this is so, and I believe it to be, then choosing your first employer carefully should stand you in good stead to succeed. As with anything in your working life, maximizing competitive advantages that may be available to you as young advocates through thoughtful career planning will hopefully allow you to avoid retracing steps later in your career.

You should, as well, use the practicing bar in which you work to your best advantage. A great deal of information can be obtained from other, more experienced counsel who practice law around you. As a new advocate, you may draw on the experiences of others for some time after your admission. Use this opportunity to gain experience by watching others and by asking as many questions as you can.

Much of your legal career has been spent studying the law. Your quest for information upon admission should be much more broadly-based. It should include attempting to ascertain the particular attitudes of the judges before whom you will be appearing as well as the habits and skills of opposing counsel. Sometimes, it will even extend to gathering available information about a particularly important witness to a proceeding, such as an expert. The latter case may simply mean attempting to secure transcripts of previous testimony given by the expert that may afford insight into their particular view of the field in which they work. 
You are, as a young lawyer, about to enter a world in which you are an advocate, not a judge. All of the human qualities that you have used with considerable success to achieve your goals as a student will be vital to your development as an advocate. In order to be successful you must, in your own mind, judge the conduct of your client in order to prepare to meet both the case advanced by the other side, as well as the possible opinions held by the trier of the case. However, your own moral judgment of your client's actions, in so far as it may impact on your passion and commitment to defend him or her, has no place on the scales with which you weigh your dedication to the case.

At first, this pitfall may be difficult to avoid. At times, public opinion will be solidly against the position you must take in defending the case at hand. Your comfort in the position you occupy will come from your understanding that you are being retained for your representation and not your moral judgment. As has often been said, you will begin to be paid for your judgment when people refer to you as "Your Honour." Until that time, use all of your energy to attempt to shape, not make, the final judgment that will ultimately be made in each case.

\section{The ETHicAl Side}

I have already addressed some of the human qualities that I feel are important to successful advocacy. Respect is one of the most powerful weapons in the arsenal of a good advocate. Very often the mere presence of a respected advocate in a courtroom is enough to change the atmosphere of a proceeding. Why does that happen? My view is that those who produce that kind of presence are men and women who have an uncommon combination of honesty, integrity, and a reputation for hard work. In other words, they are people who have gained a great respect from those with whom they interact in their work. Incidentally, it should be observed that respect, as a by-product, will often produce a considerable degree of fear in your opponent that may help to create the kind of favourable and prompt result it might not produce for others.

Professional respect is one of those characteristics that you must begin to pursue upon your admission to the bar. It will take much more work to achieve than almost anything else you have pursued in your life. Of course, it is not judged by some final exam upon which you will be scored. Rather, it is something to which you ought to commit a great deal of the life energy that you bring to the practice of law throughout your career. It will take much time, (measured in years, not months) to attain and require constant grooming through an adherence to the cardinal virtues of temperance, fortitude, prudence, and justice. As a core value, it will have the importance of hard work and pride in doing quality work to the best of your ability - even when that work becomes repetitive and routine. More importantly, the quest for professional respect must be pursued with an unbending commitment to respect for others with whom you interact, whether they are the indigents of the world or those to whom life has been most kind.

Finally, and perhaps most importantly, once attained through years of hard work, it can be lost in a moment when one fails to be mindful of any of its constituent elements. Engaging in conduct that lacks integrity, being dishonest with others, and conduct lacking candour all have the potential of damaging others' respect for you. One failure in this area often serves as a signpost for others with whom you work that, once committed, will be difficult to erase. 


\section{Well-known Ontario advocate Earl Cherniak put it thus:}

While reputation depends on many factors, the single most important one, without which the advocate cannot function, is that of fairness and honesty in dealings with the court and fellow lawyers. Lord Birkett put it this way:

he must be a man of character. The Court must be able to rely on the advocate's word; his word must indeed be his bond... The advocate has a duty to his client, a duty to the Court, and a duty to the State; but he has above all a duty to himself that he shall be, as far as lies in his power, a man of integrity. No profession calls for higher standards of honour and uprightness, and no profession, perhaps, offers greater temptations to forsake them. ${ }^{2}$

How will you know when you have begun to achieve such a reputation? It will have happened when at some point in your career, you begin to talk and everyone listens, and listens not simply to be courteous. Until then, there are important things that can be done to make up for a lack of professional reputation because of your status as a young advocate.

I am often present in courtrooms with young lawyers who stand before judges and attempt to persuade through the use of oratory alone. Without question, good oratory is an important tool of the effective advocate. However, those who come with oratory skills and nothing more usually find that their views either do not prevail or count for very little.

The best support for a young advocate's opinion that I have found is persuasive and (hopefully) binding legal precedent. A good, well-constructed argument, buttressed with such precedent, relies on the respect that the judge will have for the author of that precedent.

I remember the excitement I felt as a young lawyer when I found a precedent of $\mathrm{Mr}$. Justice G. Arthur Martin of the Ontario Court of Appeal that supported a position I was advancing in a proceeding. He was, during his time, a judge without equal in this country. The respect with which his judgments were held was unsurpassed and very often judgments of the Supreme Court of Canada would be hinged to some precedent he had previously written. During your career, there will be judges who are held in similar regard in the country. Find them and rely on the respect with which they are held to help you achieve success. In the process, you will begin to establish your own reputation with the judges before whom you appear. Judges will come to know that when your name appears on the docket of cases, they can feel comfortable that they will be treated to counsel who will not simply make their job easier, but also will more likely make their judgment right.

\section{Preparation}

I have already alluded to the importance of preparation to the successful advocate. It is probably the single most important contributor to success. Those of you who have spent time watching good counsel work may be misled into believing that achieving success is simply a matter of reading the available material in advance of the proceeding. Nothing could be 
further from reality. The presentation in the courtroom is but the tip of a very deep iceberg that has taken a great many hours to construct.

It is therefore critical to a successful outcome that counsel know every detail of the case that they are about to represent. In trial situations, this must include knowing the evidence expected to be gained from a particular witness better than the witness herself. It must, of necessity, include knowledge, insofar as it can be gained, of the factual basis for the opposing party's case. Once the evidence has been committed to memory, an overall strategy or road map to the desired result must be formulated.

Next, the legal framework within which the case will be presented must be researched and scrutinized exhaustively. It will be of no assistance to your case if a key evidentiary component you intend to rely upon suffers from some legal frailty that may prevent its admission. This kind of problem can have both a direct and an indirect impact on your case. The direct impact, of course, is that the evidence may not be admissible to assist you in the presentation of your case. The indirect impact is that if you fail to see the legal issue and are not prepared to defend that part of the case from challenge, there will be collateral damage to your credibility in the proceeding. This may be especially important when it comes to asking the trier of fact to accept your final submission. Closed files of good advocates are filled with unused legal precedents and briefs on issues that were thoroughly researched, prepared, and kept close at hand to meet a possible attack that never came.

In conducting your research, focus on precedent that will be binding or, at the very least, persuasive in the courts in which you practice. In this regard, it is important to know the reputations of the judgment writers before relying upon them. As is well-known, some courts enjoy a reputation for correctness that others do not.

Obviously, all of the available precedents must be considered against the prevailing view of the Supreme Court of Canada if it has expressed an opinion on the subject. It should always be resorted to as your primary source of legal research. This is especially true since the enactment of the Canadian Charter of Rights and Freedoms. ${ }^{3}$ To say that conventional legal wisdom has been turned on its ear since 1982 is a classic understatement.

\section{Vi. Presentation}

You must always be aware that in many respects, you are on trial each time you appear in a courtroom. While primarily engaging in assessing the strength of your case, judges and juries, consciously or otherwise, will form opinions about you based on the thoroughness of your trial preparation through your presentation. Although a well thought-out presentation is sometimes not apparent, a poorly prepared one is almost impossible to conceal. As such, it must be avoided at all costs, for its effects will cascade down upon you and make it difficult at the end of the day to persuade the trier that your closing submission - indeed your very defense in the case - is worthy of belief and acceptance. 


\section{EXAMINATION OF WITNESSES}

\section{A. DIRECT EXAMINATION}

The art of examining witnesses is at least as difficult to master as that of crossexamination. As observers, we are inclined to be impressed by the drama associated with an able, pointed, and devastating cross-examination. However, a masterful examination of a witness can provide a trier with the kind of confident assurance that the case being presented is worthy of complete acceptance. When properly done, the resulting presentation of evidence is very often unassailable.

I have always felt that a truly effective direct examination results when the witness gives all of the potential evidence he or she has to give in a well-organized and comprehensible manner, while the examining counsel has remained virtually invisible in the courtroom. In such circumstances, the witness both holds the centre stage and forms the focus of the trier's attention. As counsel, there may be a temptation to try to steal some of the spotlight to demonstrate that a great deal of work has been done preparing the case and the witness for presentation to the court. Humility, therefore, is an important attribute of counsel on direct examination.

Much time must have been spent in preparing the witness to testify. This would include both a thorough review of the evidence gathered from the witness or given before trial, and a coldly critical assessment of the witness's character strengths and weaknesses as revealed through interviews. In the final analysis, when direct examination is done properly, in coming to a conclusion, the trier of fact is rightly left to consider only the credibility of the witness and not that of trial counsel. An overly coaxed presentation of a particular witness's testimony will appear stilted and may suffer the additional problem that counsel may appear too involved in the advancement of the case. Such presentations will frequently be given little weight by both judges and juries, who will quite likely view them with a jaundiced eye. In addition, at the close of the case when the closing statement is made, it may not enjoy the respect it otherwise would have had it followed a reasonably objective presentation of the evidence.

The presentation of evidence on direct examination, as stated previously, must begin with counsel having a thorough knowledge of the evidence a particular witness is capable of delivering. Witnesses often neglect to mention important pieces of evidence while testifying. This may arise for various reasons, not the least of which is the foreign nature of trial proceedings to lay persons. Nervousness is the most common reason for a delivery of testimony that is less than complete. As counsel, while maintaining professional distance, the advocate must establish a rapport with an important witness. That rapport will allow for timely intervention during the delivery of evidence without being off-putting to the witness. One must always bear in mind the crucial need for counsel to allow the witness to deliver the evidence, insofar as it is possible, in a manner with which she or he is comfortable.

Counsel must be aware that such familiarity with the evidence comes from knowing a case well sometimes inclines young counsel to intervene at the very moment that a particular witness deviates from what he or she had given in a previous statement or statements. It may be that the witness simply overlooked the evidence and will return to it later in the testimony. 
If there is a general rule to adhere to in such cases, it would be to allow the witness to give the evidence as a largely uninterrupted narrative and later return to fill in any gaps in the account, unless the context of the evidence will be lost if intervention does not occur immediately. This, of course, would have to be qualified by such exceptions as are presented by an extraordinarily nervous, young, or elderly witness who might require assistance, through questioning, to attempt to achieve a level of comfort with the task at hand. The same would hold true in cases involving the calling of expert testimony, though for obviously different reasons.

As stated previously, the principle that applies to ensuring a successful examination-inchief is that counsel should always be an adjunct to the witness, not the star of the performance. Otherwise, the delivery of witnesses' testimony and, indeed, the case itself, will lack the required spontaneity and life necessary to gain acceptance from the trier of fact. As a result, the witness should never be led in relation to the crucial issue about which they have been called upon to testify. The testimony of a witness on such important issues ought to be theirs and theirs alone.

That is not to say that counsel is without recourse in trying to draw a judge or a jury's attention to a particularly important part of the evidence that a witness is about to give. As Justice G. Arthur Martin once said:

[y]ou should never read from a prepared question because it loses its effect of spontaneity, but you shouldn't be afraid to think about it in advance. Speaking of spontaneity, I once read that the great English barrister, Sir Patrick Hastings, had the knack, when he was examining his own witness, of appearing to hear this very interesting and spontaneous information for the first time and sharing this interest with the jury. ${ }^{4}$

\section{B. CROSS-EXAMINATION}

\section{GENERALLY}

Seemingly, much more has been written about the subject of cross-examination than that of direct examination. It is an element of an advocate's skills with the potential to have a profound impact on the outcome of a trial. Effective cross-examination calls into question the probative value, and very often the truth, of a witness's testimony. It has an additional feature that may be equally important. When done properly, it defines the trial advocate as an individual who ought to be given great deference by the trier of fact. Successful crossexamination of an important witness can deflate the case under attack. Alternatively, it can provide you with the necessary confirmation of your case.

The first consideration in formulating a strategy for the cross-examination of a particular witness is to address the question of whether it is beneficial to cross-examine at all. Many inexperienced defense counsel feel that it is obligatory that they engage in some kind of cross-examination of each witness in order to fulfill their duty to the client to produce some 
kind - indeed, any kind - of work product, no matter how incidental it is to the case. To simply sit and say nothing somehow seems to indicate that one's fee is not being earned.

Nothing could be further from the truth. A great number of cases in which I have been involved have resulted in the conviction of the accused through an inept and poorly prepared cross-examination by opposing counsel. Despite being one of the greatest gifts defense counsel can bestow upon a prosecutor, most recipients of such a gift rarely thank its donor for the unexpected windfall. When such blunders occur, the opposing party derives a significant evidentiary benefit from the questioning. That benefit is usually accompanied by serious damage done to the credibility of counsel in the eyes of the trier of fact, especially in jury cases. Again, this can cause serious problems at the close of the trial when it comes time for counsel to rise and deliver a closing address that one hopes will sway the jury in favour of acquittal.

\section{CROSS-EXAMINATION AT PRELIMINARY HEARINGS}

The cross-examination of witnesses must be approached differently at a preliminary hearing than at a trial. Recent pronouncements from the Supreme Court of Canada ${ }^{5}$ have made the test for committal for trial a virtual legal speed bump on the road to possible conviction. No cross-examination at the preliminary hearing, no matter how devastating, will sufficiently impair a witness's credibility to result in a successful motion to discharge the accused at that point on the basis of credibility alone.

It ought to be borne in mind that while the preliminary hearing can serve as an opportunity to explore important issues with professional witnesses such as police officers, it can also serve to warn the Crown about possible frailties in the case that may not be apparent in the investigation and that might be remedied before trial. One must, therefore, approach the preliminary hearing with great care, cross-examining only on those issues that, out of necessity, must be dealt with to properly prepare for trial. The relative legal insignificance of the preliminary hearing ought not lull counsel into believing that little preparation and thought need go into preparing for it.

\section{CROSS-EXAMINATION AT TRIAL}

If the hallmark of direct examination is invisibility of counsel during witness testimony, the opposite is the prime feature of cross-examination. Here, counsel must assume centre stage, taking control of the witness' direction of travel. As far as possible, the witness ought not be allowed to venture beyond the strict bounds of the plan established by cross-examining counsel.

As with everything else in trial work, an effective cross-examination requires meticulous preparation, precise organization, and careful delivery. Of necessity, it also requires a great deal of operational strategy in the courtroom. Preparing to cross-examine the important

See e.g. R. v. Charemski, [1998] 1 S.C.R. 679. In that case, there were three possible causes of death; although homicide was only one possibility, it was nevertheless sufficient to displace the burden on the Crown to adduce some evidence on each of the essential ingredients of the offence that could, if believed, result in conviction. 
witnesses ought to begin early in the proceedings, as soon as all of the information contained in the file has been carefully reviewed.

However, much more must be done to prepare for cross-examination. The very nature of the relationship between a witness and counsel on cross-examination is dynamic. There is, first of all, the potential for a power imbalance between the two protagonists. This may or may not be of great significance depending on such things as the degree of any imbalance, the nature and importance of the witness's testimony, and the character of the witness involved. A witness who presents him or herself as an apparently honest, deferential victim of crime must be approached much differently than one whose pedigree is measured by the number of feet of criminal record he carries as baggage to the witness box.

As a general rule, one must regard a witness on cross-examination as a potentially hostile individual in the sense that he or she may stand in the way of the case being advanced by the cross-examining party. This category of witness will, in most cases, be on guard with respect to conceding points to opposing counsel, whether it is apparently so or not. A particularly intuitive and deceptive witness, for example, will require much care and planning before the cross-examination begins. In such cases, it will be necessary to avoid taking a direct route to the crucial question, or questions, upon which you hope to either discredit the witness or use the witness to support your theory of the case. When the witness is an important one, I have always tried to approach this kind of cross-examination in the following way.

First, identify the issues that have the potential of advancing your case, whether through some admission that is supportive of your case, or on some matter that is detrimental to the case for the opposing side and upon which the witness to be cross-examined has evidence to give. Second, analyze the background evidence that must be established through the witness' testimony in order for the crucial question to be asked and not avoided. Third, formulate the strategic questions as well as the order of those questions that will hopefully lead to the desired answer and none other.

The final step in executing the strategy will vary depending on the experience counsel has with the witness as the cross-examination unfolds. It may be necessary to switch from one crucial issue to another, advancing each one a little at a time in a way that does not communicate to the witness that there is any clear direction or plan to the exchange. In this regard, it may be necessary to engage in non-verbal communication with the witness in an attempt to allay any general feelings of mistrust that he or she might harbour towards counsel. The deceptive witness will attempt in most cases to anticipate the general direction that counsel appear to be taking. Hence, disguising direction is often the key to success. Sometimes a witness' attempt to anticipate the direction that cross-examination will take is so apparent that it can be utilized to discredit the witness.

In sizing up the deceptive witness, it may be necessary to resort to some simple tools of common sense that counsel has at his or her disposal when assessing human beings. It has been said that in many cases, those men and women with the greatest passion for advocacy are students of human nature. If that is so, as I believe it to be, the skills that one develops throughout life in assessing human nature surely play a critical role in formulating and executing a plan for cross-examination. Innovation and creativity, while not essential ingredients to effective cross-examination, are skills that will, over time, be developed by 
hard-working advocates. Such skills will be called into service even when the most wellprepared cross-examination veers off in an unanticipated direction.

On the other hand, the honest witness must be approached in a much different manner. The hallmark of the testimony provided by this type of individual is an attempt to be just that: honest. In such cases, it serves little purpose to attack the witness, as the judge or jury or both may recoil from what appears to be unfair treatment. It has been said that most people rarely know justice when they see it but are able to identify injustice almost every time. Engaging in conduct that evinces an unjust exploitation of an apparently honest witness can cause serious difficulty for the case being advanced. It ought to be avoided in favour of a crossexamination that attempts to plant seeds of doubt by utilizing the natural tendencies of honest citizens to acknowledge such possibilities as mistake, misapprehension, and error in observation or opinion.

Regardless of the kind of witness being presented, your cross-examination should conclude on the crucial question or questions that the witness will hopefully answer in your favour. The primacy rule that people remember best what they heard last and what was most prominent ought to be applied at the close of any effective cross-examination.

\section{ADDRESSING THE JURY}

\section{A. The Opening Statement}

\section{GENERALLY}

Whether it be done on behalf of the Crown or the defense, the opening statement presents an opportunity to do something that all counsel must commit themselves to doing with every opportunity that presents itself: speak directly to the trier of fact. This ought to be handled in different ways depending on which side you represent.

\section{OPENING FOR THE CROWN}

As Crown counsel, the opening allows one to lay out in brief fashion what the Crown intends to prove in a particular case. While it need not be lengthy, the opening should provide a basic road map for the jury, so that they can begin to open up their minds to receive the evidence and assess it. The opening ought to be more empirical than theatrical. At the outset of the trial, the jury is in no position to judge the worth of the case for the Crown or defense and, more importantly, to assign weight to the statements of counsel they have only just met. It is wrong to make strident statements to the trier about what the Crown believes the evidence will add up to at the end of the day. Rather, the opening should be a time for the Crown to begin to direct the jury's attention to a direction of travel through the evidence. Incidentally, an objective, firm, and relatively dispassionate opening that avoids the use of excessive oration may also avoid an early labelling of the Crown as "the prosecutor."

While the jury should always be left with the impression that the case for the Crown is being guided by a firm and steady hand, it must also be seen to be guided by a hand that is, above all else, fair. Through the course of my career I have experimented with subtle variations of these factors. I have found through experience that it is perilous for the Crown 
in its opening to appear to be so fair as to appear fair in the extreme, and thus possibly lacking in conviction of the case being presented. At some point the jury, who are always somewhat uncomfortable about standing in judgment of one of their fellow citizens, may see this kind of approach as a license to acquit, even where a conviction ought to be the result. Finding a comfort level that meets the obligations cast upon the Crown and yet provides counsel with a measure of situational control is a matter of personal style.

\section{OPENING FOR THE DEFENSE}

Opening for the defense is a matter of some dispute. Some counsel prefer not to do so since, by the time the defense is called upon to answer the case for the Crown, most juries ought to know the essence of the defense that is being pleaded. However, most counsel subscribe to the view that an opening ought to be given, if for no other reason than that it affords one more opportunity to get the defense theory before the jury in some sort of orderly and understandable fashion.

As is the case with the Crown, resorting to a detailed recitation of the evidence hoped to be gained from the witnesses should be avoided. This is so for two reasons: first, a witness, after completing his or her testimony, may not have yielded the evidence promised, and second, he or she may have yielded it in significantly different form than promised by counsel.

More important, and potentially devastating, is the situation that sometimes occurs when the Crown has had a particularly successful outing with a principal defense witness on crossexamination, to the point that defense counsel is forced to decide not to subject other witnesses to a similar and potentially devastating attack. Promising to deliver evidence and then failing to do so in these circumstances sends a powerful message to the jury about the strength of the case being advanced. ${ }^{6}$ In circumstances where this kind of potential looms at the opening of the defense, it would be better to adopt a much more general approach, leaving open the prospect of shortening the witness list without apparently having done so.

\section{B. The Closing AdDResS}

The closing presents the advocate with the final, and perhaps most important, opportunity to persuade the trier of fact of the strength of the case being advanced. If the trial has been one in which counsel has diligently and successfully built a reputation for honesty, integrity, and maturity with the jury, the time is then ripe to use the respect gained to its best advantage.

Preparation of the closing ought to have been begun before the commencement of the trial, and been updated and amended to conform with the evidence as the trial has proceeded. While oratory plays a significant role in the closing, there is no place for editorial license in playing fast and loose with the evidence. Nothing is more devastating to a closing submission

Although I have used as an example the opening by the defense, the same calamity can befall the Crown who, in the opening, promises to deliver a witness and fails to do so. In this regard see $R$. $v$. Jolivet, [2000] 1 S.C.R. 751. Although the conviction was upheld on the overall weight of the evidence, the Court was of the view that the defense ought to have been allowed to comment, in its closing address, on the failure of the Crown to deliver the promised witness. 
than an interruption by the presiding judge correcting counsel on a serious misstatement of the evidence.

As opposing counsel, the closing address ought not be objected to during its delivery except where there has been an egregious misstatement of evidence of a central issue that requires immediate correction. In such cases, a subtle look of shock, disbelief, or concern directed towards the presiding judge will usually be enough to prompt a courteous intervention. In those cases where your submission will follow such a misstatement, you will be able to correct the error by pointing to the actual evidence upon which serious error has taken place. This should be done with respect and not disdain.

Part of the boilerplate of the Crown submission should deal with the importance of the duty and obligation that the jury owes to the community, and the vital necessity of responsibility that lays upon their shoulders if proof of the offense has been made out. On behalf of the accused, the cornerstone of the closing is invariably the presumption of innocence and the doctrine of proof beyond reasonable doubt. The Supreme Court of Canada has recently revisited the subject of the appropriate terms to be put to the jury, and has provided clear direction to trial judges that will make the persuasive task of defense counsel somewhat easier. In clear and concise terms, the judge will thus instruct the jury that the burden of proof is very high indeed. ${ }^{7}$

Before leaving this topic it should be observed that the closing address can often be buttressed in the pre-charge conference that has hopefully occurred before the delivery of the closing addresses or, at the very latest, after they have been made. Counsel ought to be prepared to defend their factual and legal positions to the trial judge with a short, concise summary of both the evidence and supporting precedent, where required. No advantage can be greater to a party than to have the presiding judge place emphasis on an issue important to one side. Be prepared to defend the position you have taken.

Finally, there are simple rules that ought to be kept in mind in crafting one's closing. They are: keep it simple, get it right, and make it real.

\section{Civility}

Perhaps no area of the practice of trial advocacy has seen as much change as the topic of civility and its apparent decline in the last decade. The proliferation of cases relating to inappropriate trial tactics dominates the legal landscape in a way not seen before. The root cause of this change is not readily identifiable. What is clear, however, is an ever-increasing incidence of conduct that goes far beyond the bounds of propriety by both Crown and defense and that, in an inordinate number of cases, is of sufficient magnitude to constitute reversible error. Curiously, a great deal of the inappropriate conduct passes almost unnoticed, or at the very least unchecked, by trial judges. It is most commonly, and sometimes with almost merciless consequences, remedied at the appellate level - merciless in the sense that the conduct of trial counsel and not the strength of the case becomes the focus of appellate attention. 
What is the reason for this change in behaviour? My view is that there is an increasing reluctance on the part of trial judges to interfere with the conduct of trial counsel. Prior to the enactment of the Charter, trial and appellate judges clearly approached cases from a verdict orientation - that is, what was the appropriate verdict that ought to occur on the admissible evidence presented at the trial? The high water mark of this doctrine was the case of $R$. v. $\mathrm{Wray}^{8}$ in 1971. At both the appellate and Supreme Court level the invocation of former s. 613 (now s. 686) of the Criminal Code ${ }^{9}$ saved many convictions and acquittals from retrial over the years.

However, early in the Charter's history, the Supreme Court of Canada served notice that a quantum shift in orientation had begun to occur towards an issue-based approach to appellate review. As the Charter began to evolve, it became apparent that the Supreme Court of Canada was not interested in ex post facto reviews of state-sponsored investigatory conduct. ${ }^{10}$ Nor was it about to suffer breaches of the constitutional rights of suspects and accused persons simply because impugned evidence pointed towards, or in extreme cases provided incontrovertible evidence of, a suspect's guilt."

This new judicial civility directed towards the accused and his or her constitutional rights was not well received by either the police or Crown counsel. In the past, trials had seen all probative evidence that was logically relevant and not otherwise inadmissible received into evidence, no matter how reprehensible the method of obtaining that evidence had been. The trial, after all, was nothing more and nothing less than a search for the truth. The shift toward focusing upon such things as how evidence had been gathered and whether an accused was being treated fairly by the trial process has created more of a contest-like trial atmosphere. Inside it, defense counsel must attempt to suppress evidence that has been gathered, while the Crown continues to attempt to cling - albeit without much success - to the search-forthe-truth approach to admissibility and trial process.

Perhaps it was inevitable that in this new environment, Crown counsel would recoil against those situations where they were in possession of highly probative evidence pointing towards guilt, that, owing to some Charter infringement, had kept such evidence firmly on the sidelines. In any event, the 1990s have been filled with reported incidents in which Crown counsel have stepped well beyond the bounds of acceptable behaviour in pursuit of convictions. As the new millennium unfolds, the patience of appellate courts and the Supreme Court of Canada has worn very thin with respect to disreputable conduct by counsel, and especially Crown counsel.

\section{Defense Conduct}

Despite being an area of perpetual interest to the public, the ethical practices of defense counsel have not been all that much different from those of Crown counsel during the past decade. There is a striking shrillness in tone and a similar "win at all costs" mentality to the way in which too many defenses are pursued. This trend has been attributed to our adoption 
of strongly-held and practiced views of American advocates from the 1960s through the 1990s.

In what most likely will become the conduct manual of all Canadian advocates in the years to come, Ethics and Canadian Criminal Law, ${ }^{12}$ Justice Michel Proulx and David Layton make this important observation regarding this trend that has held favour in Canada:

\footnotetext{
The lawyer's necessary and legitimate role as champion of the client within a rights-based adversarial system is the defining principle for adherents of this approach. The advancement of a client's rights within the system is the greater good that supports the lawyer's function as so-called "neutral partisan" or "client's friend". This especially strong "role morality" begins to crowd out the notion that a lawyer can legitimately pursue a personal morality or larger duty to the public interest. ${ }^{13}$
}

However, the authors noted that a new challenge to that notion of legal ethics and consequent loyalties is currently being mounted, at least in academic circles:

While these academics do not agree on all things, their approach is marked by a belief that good lawyering involves the active exercise of personal morality and a more acute sense of responsibility to society at large.

In some ways, the New Ethics approach reflects a return to the more traditional notion of tempered zealousness in lawyering. It certainly rejects a role morality according to which the lawyer almost unquestioningly adopts and promotes the values of the client. ${ }^{14}$

While the focus here is on the conduct of Crown counsel, it should not be taken as any concession that counsel for the defense have claimed and defended the moral high ground during this period. The record is no better on either side of the counsel table. ${ }^{15}$

\section{Crown Conduct}

It seems apparent from the reported cases that an increasing number of Crown counsel have seriously strayed from the strictures of the Supreme Court of Canada's pronouncements in Boucher v. R. ${ }^{16}$ What seems to have been lost here is more than the obligations owed to courts and to the accused. Also lost is any fundamental sense of self-preservation from professional attack, by civil action or otherwise, that egregious conduct may bring if engaged in by a prosecutor.

The world in which prosecutors assess investigations and prosecute cases has evolved rapidly over the past several years. Whereas in the past, prosecutors worked in relative

12 (Toronto: Irwin Law, 2001).

13 Ibid. at 4

$14 \quad$ Ibid. at 5 .

15 See e.g. R. v. Murray (2000), 48 O.R. (3d) 544 (Gen. Div.), in which a lawyer was acquitted of obstruction of justice in relation to his concealment of certain video tapes characterized by the Court as indescribably horrible sexual assaults of Leslie Mahaffy and Kristen French in the Paul Bernardo case, infra note 23. Although counsel's actions in attending Bernardo's home (where the assaults taken place and the videos had been made and hidden in a ceiling) were not the subject of the obstruction charge, counsel had made a pact sealed with handshakes, hugs, and lunch on Bernardo's deck before leaving the premises. 
obscurity, the vaulting of criminal law to the forefront of hard-news journalism has placed new pressures on police agencies to deliver charges and, in turn, on prosecutors to deliver convictions. Difficulties in objective case assessment by Crown counsel have arisen from an increased reliance among police on legal opinions provided by the Crown in the investigative stage of crime-solving. This has tended to blur the demarcation lines of responsibility between the Crown and the police, tending to promote a more homogenized approach to crime-solving and prosecution.

It may be that these pressures have contributed to the abusive cross-examination tactics and inflammatory closing addresses by Crown counsel that have proliferated in the last decade. Let us look at some of those situations.

In $R$. v. Logiacco, ${ }^{17}$ the accused was called a "bare-faced liar" and was subjected to extensive cross-examination on his knowledge of the Bible. As well, he was examined at length as to whether police officers in unrelated cases had been telling the truth while testifying. In ordering a new trial, Cory J. observed that:

[t]here is no doubt that cross-examination is a very powerful weapon in the hands of a skilled and wellprepared advocate. There is no reason why a cross-examination cannot be conducted with some measure of respect for a witness which would not be inconsistent with a skilful, probing and devastating crossexamination. $^{18}$

As well, asking the accused to comment upon the honesty of other witnesses is clearly inappropriate and has been for many, many years. This type of attack occurs most frequently in sexual assault cases where conventional wisdom holds that women would not subject themselves to the stress of a criminal trial unless their complaint were true. Lost to Crown counsel somewhere in the process is the notion of fundamental trial fairness. Repeated requests of the accused and his supporting witnesses on cross-examination to provide some explanation, any explanation, or motive for the complainant to fabricate will invariably result in the re-victimization of that complainant at the re-trial occasioned by such unacceptable questioning. ${ }^{19}$

The practice of figuratively pointing a loaded gun at the head of the accused and forcing him to either accept the rendition of the case provided by police witnesses or brand them as liars is no more acceptable than the similarly distasteful practices alluded to earlier. ${ }^{20}$

Such examples of inappropriate and unscrupulous cross-examination of the accused cross an almost boundless spectrum. Included among the more obvious reversible errors is an attack on an ultrasound operator on trial for sexual assault with evidence that he met his wife while giving her an ultrasound and that he had had consensual relationships with other 
patients. ${ }^{21}$ So, too, is the cross-examination of an accused on trial for sexual assault about his father's record of conviction for indecent assault. ${ }^{22}$

Another area that has proved problematic is the attempted use of s. 13 of the Charter to impugn the credibility of a witness by showing that he or she was aware that his testimony in one matter could not be used to incriminate him or her in another proceeding. This was the case in $R$. v. Bernardo. ${ }^{23}$ Presumably, the object of such an approach is to invite the jury to draw the inference that the testimony was false due to its being free from subsequent use by the Crown. Although not fatal to the conviction in that case, the Ontario Court of Appeal felt its use ought to have been avoided.

Although the practice of using s. 13 as a cross-examination tool has not been completely rejected, severe restrictions have been placed on its use. In $R$. v. Jabarianha, ${ }^{24}$ the Supreme Court of Canada dealt with the use of s. 13 as an implement to discredit a witness on crossexamination by implying that the witness was shielded from the use of that evidence in a later proceeding. Rare would be the case, said the Court, in which the s. 13 could be used to attempt to impeach a witness. ${ }^{25}$

It would not be fitting to conclude this short review and omit mention of a tactic that has been employed to some extent in Ontario. This approach has seen Crown counsel suggest on cross-examination that since the accused has had access to the Crown disclosure file, he is in a better position to fashion a bullet-proof story in advance of his testimony. In $R$. $v$. White ${ }^{26}$ Doherty J.A. observed that on many occasions the use of this technique, if countenanced, could turn what is the fundamental constitutional right of disclosure into a trap for the accused.

Is there a rule of thumb that might be borne in mind when counsel is about to embark upon a line of questioning that feels somewhat vicious in its nature? If there is one test that might determine whether this path ought to be taken, it might be to ask oneself: "Is this mud slinging?" If so, it must be avoided.

The by-product of this unfortunate approach to advocacy has included a litany of wrongful or fundamentally-flawed convictions in the past 12 years, including the cases regarding

R. v. Roos, [1993] O.J. No. 668 (C.A.) (QL).

R. v. Dupuis (1995), 23 O.R. (3d) 608 (C.A.).

(2000), 48 O.R. (3d) 135 (C.A.).

[2001] 3 S.C.R. 430.

Ibid. at para. 18, Major J. The protection afforded the accused by s. 13 has recently been further extended by the Supreme Court of Canada in R. v. Nöel (2002), 168 C.C.C. (3d) 193. In that case, the Court held that the accused cannot be so cross-examined unless the trial judge is satisfied that there is no realistic danger that prior testimony could be used to incriminate him or her. 
Marshall, ${ }^{27}$ Milgaard, ${ }^{28}$ Morin, ${ }^{29}$ Sophonow ${ }^{30}$ and, most recently, the case of Proulx $v$. Québec. ${ }^{31}$ Most of these cases seem to have done little to stem the flow of overzealous conduct. It may be, however, that the last of these, Proulx, will prove to be the case that carries the greatest potential for change.

The critical facts in Proulx are worth repeating. The case involved the murder of Proulx's girlfriend in Quebec in the early 1980s. In 1986, a prosecutor determined that there was not enough evidence to charge Proulx with her death. Five years later, in the midst of a sensational defamation case launched by Proulx against the Chief Investigator Tardif, (now retired), and a radio station, a witness was brought to the attention of the prosecutor through direct intervention of the civil defendants. Tardif was then invited by the prosecutor to attend a meeting where the new witness identified the eyes of Proulx, now many years later, as those of the murderer, even though when he was shown Proulx's whole face he said it was not that of the perpetrator. Tardif, the civil defendant, was then brought back into the police investigation team with the knowledge and consent of the prosecutor. The only other evidence against Proulx was a surreptitiously recorded conversation between Proulx and the deceased's father that was either inadmissible or, alternatively, proved nothing according to the Supreme Court of Canada. The accused was somehow convicted of murder. However, on appeal, the Quebec Court of Appeal reversed the conviction.

In its judgment in the malicious prosecution suit that followed, the Supreme Court of Canada clearly placed responsibility for the charging decision and the resulting prosecution on the Crown counsel in charge of the case. In their co-authored majority reasons, Iacobucci and Binnie JJ. stated in clear and unambiguous terms: "[n]or can the prosecutor rely on consultations he had with colleagues and superiors. He knew more about the case than they did and, as the holder of an important office under the Criminal Code, ... the decision to lay the charge was his and his alone." ${ }^{\prime 32}$

As a result of Proulx, the test that is to be applied in determining whether a prosecution is warranted has now been stated in clear, and perhaps troublesome terms for the Crown:

[T] he Crown must have sufficient evidence to believe that guilt could properly be proved beyond a reasonable doubt before reasonable and probable cause exists, and criminal proceedings can be initiated. A lower threshold for initiating prosecutions would be incompatible with the Prosecutor's role as a public officer charged with ensuring justice is respected and pursued. ${ }^{33}$

See Nova Scotia, Royal Commission on the Donald Marshall, Jr., Prosecution (Halifax: The Commission, 1989).

Reference re: Milgaard, [1992] I S.C.R. 866. Although it was advanced at the reference stage as a case of the wrongful conviction of an innocent man, the Supreme Court of Canada declined to accept that thesis. On the totality of the judicial record of the case, the Reference, and the fresh evidence, the Court held that it had not been established beyond reasonable doubt, or on a preponderance of evidence, that Milgaard was innocent of murder. There was sufficient evidence, however to warrant a new trial. See Ontario, Report of the Commission on the Proceedings Involving Guy Paul Morin (Toronto: Ministry of the Attorney General, 1998). Manitoba Justice <www.gov.mb.ca/justice/sophonow/intro/index.html>.

[2001] S.C.J. No. 65 (QL) [Proulx].

Ibid. at para. 33 [citations omitted].

Ibid. at para. 31 [emphasis added]. 
This judgment leaves us with a clear path of responsibility directly to the prosecutor who makes the charging call and prosecutes the case. Whether that will cause a chill to occur in the ranks of Crown counsel across the country remains to be seen. However, the thought of becoming a civil defendant may be more than enough to reorient the approach, and refocus the unbridled passion of even the most zealous prosecutors in respect of all that they do in the name of the Attorney-General. ${ }^{34}$

\section{Conclusion}

As I close, I hope that what I have said has some relevance as you begin developing your own thoughts and solidifying your values on the subject of advocacy - thoughts and values that you will continue to build upon throughout your career. I believe that if you hold true to the stricture of good advocacy, both practical and ethical, you will find it to be a relentless and demanding master. Yet it will also provide you with some of the greatest rewards that can ever be bestowed upon a professional. They are that you may, for at least brief moments throughout your career, be able to perhaps make a difference, and to see the importance of your contribution to shaping the development of our country, its laws, and its people.

Practicing good advocacy in the new millennium may not be all that different than it was in the century just past. Challenges no doubt face us. Some of them have at least been identified here today. The evolution of the practice of law, and of the law itself, is built upon the careful and steady historical ascendancy of precedent. There is no meteoric change on the horizon. There are, however, practices and rules that need to be critically viewed and changed in every age. Ours is no different. It is your challenge to confront those you see, and attempt to help induce healthy change where it is warranted.

Finally, not all of you will be moved to commit yourselves to a task that demands so much of your life energy. To some it will be a job, to others a profession, and to some an avocation. Find a balance that works for you and for those to whom you have committed, or will commit yourself to, in your personal lives.

This particular approach is somewhat similar to that promoted by the late Supreme Court Justice John Sopinka in a controversial article that queried the need for a new tort of Crown negligence for prosecutorial and police misconduct, or alternatively a new constitutional tort under section 24(1) of the Charter, supra note 3. See J. Sopinka, "Malicious Prosecution: Invasion of Charter Interests" (1995) 74 Can. Bar Rev. 366. 